\title{
HOUSING SATISFACTION IN FINLAND WITH REGARD TO AREA, DWELLING TYPE AND TENURE STATUS
}

\author{
Maria Pekkonen, Ulla Haverinen-Shaughnessy \\ Department of Health Protection, National Institute for Health and Welfare, Kuopio, Finland
}

\section{SUMMARY}

Aim: This study presents a comprehensive examination of housing satisfaction in Finland and how it associates with different types of residential area, dwelling and tenure status taking into account socio-demographic and socioeconomic variables.

Method: Associations between housing satisfaction and types of residential area, dwelling and tenure status were analysed by multivariate logistic regression using questionnaire data from a random sample of Finnish households (response rate $44 \%, N=1,308$ ).

Results: Respondents from rural areas and those living in houses were statistically significantly $(p<0.05)$ more satisfied with indoor thermal conditions in summer than respondents living in city centres (OR 2.01) and apartments (OR 1.75), respectively. Homeowners were more satisfied with the dwelling (OR 3.19), indoor air quality (OR 1.73) and thermal conditions in winter (OR 2.63), and reported moisture or mould damage (OR 0.37 ) and neighbour noise disturbance (OR 0.60 ) less frequently than tenants.

Conclusion: Based on this study, the most important factors determining differences in housing satisfaction were tenure status and type of the dwelling. In the context of housing policy development, these results warrant a special consideration of housing quality in rental apartments. The results can also be used for making comparative assessments (e.g. detecting areas of relative strengths or needing improvement) of multifamily buildings and residential areas.

Key words: housing and health survey, living environment, occupant perception, socioeconomic status

Address for correspondence: M. Pekkonen, Department of Health Protection, National Institute for Health and Welfare, 70701 Kuopio, Finland. E-mail: maria.pekkonen@thl.fi

\section{INTRODUCTION}

Housing is an important area of research because we spend many hours at home (1), and physical, chemical and biological factors in the home environment can be detrimental to our health and productivity (2). For example, microbial growth due to dampness or moisture damage is a well-known risk factor for asthma symptoms and other respiratory symptoms (3). Noise is associated with sleep disturbance, hearing impairment, myocardial infarction, ischaemic heart disease, and cardiovascular diseases (4-7). Satisfaction with one's dwelling has also been associated with health status: respondents who were satisfied with their dwellings being more likely to report better physical and mental health and also health satisfaction (8).

The housing and living environments have been increasingly recognised as social determinants of health. In general, people with lower socioeconomic position have the worst housing conditions, potentially experiencing, for example, thermal discomfort, exposure to environmental tobacco smoke and dampness and mould in their dwellings as well as exposure to noise and outdoor pollution in their living environment (9-13). Therefore, socioeconomic variables are strong determinants of environmental risks, causing inequalities. These inequalities can be expressed in relation to factors such as income, education, employment, age, gender, and race/ethnicity.
Until 1990, Finland has been a country with a low degree of relative poverty and income inequalities. Since the recession of the early 1990s, relative poverty and income inequalities have grown. The growth rate for income inequality and relative poverty has been rapid enough to draw international attention $(14,15)$. The main reasons for the growing differences have been changes in manufacturing and the labour market (e.g. increasing unemployment and short-term employment). In parallel, progressive taxation and income transfers to equalize income differences have diminished. Further on, differences in income from capital growth have been resulting from release and globalization of finance as well as change of production.

Social and welfare inequalities can be influenced by health and housing policies, with special emphasis on different population groups where intervention is needed. However, knowledge on differences in environmental health risks between different population groups caused by housing quality in Finland is currently scarce. Research may help to identify the groups with higher environmental health risks related to housing. In addition, information about typical levels of housing satisfaction may be useful for reference purposes, to be utilized in comparative assessments in selected residential areas or samples of buildings for detecting areas of relative strengths or those needing improvement. For this purpose, building owners and decision-makers need information about how housing satisfaction vary between different areas, building types and tenure status. 
This study presents a comprehensive examination of housing satisfaction in Finland and how it associates with different types of residential area, dwelling and tenure status, taking into account socio-demographic and socioeconomic variables. The underlying null-hypothesis is that housing quality is independent of the types of residential area, dwelling and tenure status.

\section{MATERIALS AND METHODS}

The study material consisted of nationwide cross-sectional survey data collected in 2007. The housing and health survey covered a random sample of 3,000 households in Finland drawn from the Population Register Centre (FPRC) database including one 18-75 year old Finnish speaking resident per household. The residents could participate either by completing and returning a paper questionnaire or by completing the same questionnaire via the Internet. Participation in the study was voluntary. Privacy protection was in accordance with the Finnish Personal Data Act (16) as well as the requirements of the National Institute for Health and Welfare. The questionnaire included a total of 100 questions about respondents' background, living environment and residence (e.g., hygiene, physical and biological conditions, chemical impurities) as well as safety of the living environment and respondents' health and well-being. The response rate was $44 \%(\mathrm{~N}=1,308)$. The survey was described in more detail elsewhere (17).

First, we identified variables that indicate housing satisfaction, including having enough space in dwelling, satisfaction with the dwelling and indoor air quality (IAQ), temperature conditions of the dwelling in summer and winter, noise disturbance in the dwelling or in the living environment due to traffic or neighbours, and moisture or mould damage on interior surfaces. Some of these variables were chosen based on the WHO-Europe office report (13), which presented the baseline assessment of the magnitude of environmental health inequality in the European region.

Data analyses started by assessing frequencies of independent variables and bivariate associations between the selected housing satisfaction variables and housing characteristics, including selfdefined residential areas (city/town centre, suburban area or other urban residential area, urban fringe area, semi-urban area, e.g. parish village, and rural area), dwelling types (apartment block or house, where 'house' includes a detached, semi-detached or row house), and tenure status (home owner, rental tenant). In the following analyses, we constructed models for every housing satisfaction variables by logistic regression. Outcomes were dichotomized into two categories as presented in Table 1. Analyses are illustrated in Figure 1. Models were run by a stepwise procedure. In the first step, a priori variables (Block 1) were entered in the model. A priori variables included selected housing characteristics, as well as socio-

Table 1. Formulation of variables based on questionnaire data

\begin{tabular}{|c|c|c|c|c|}
\hline \multirow[b]{2}{*}{ Variable } & \multirow[b]{2}{*}{ Question } & \multicolumn{3}{|l|}{ Dichotomizing } \\
\hline & & 1 & 0 & $\begin{array}{l}\text { Excluded from } \\
\text { analyses }\end{array}$ \\
\hline Satisfied with dwelling & $\begin{array}{l}\text { How satisfied are you with your present } \\
\text { dwelling/building? }\end{array}$ & Satisfied & $\begin{array}{l}\text { Fairly satisfied } \\
\text { Rather dissatisfied } \\
\text { Dissatisfied }\end{array}$ & No opinion/cannot tell \\
\hline Satisfied with IAQ & $\begin{array}{l}\text { How satisfied are you with the quality of the } \\
\text { indoor air in your dwelling? }\end{array}$ & Satisfied & $\begin{array}{l}\text { Fairly satisfied } \\
\text { Rather dissatisfied } \\
\text { Dissatisfied }\end{array}$ & No opinion/cannot tell \\
\hline Suitably warm in summer & $\begin{array}{l}\text { What are the temperature conditions in your } \\
\text { dwelling? You may choose more than one option.* }\end{array}$ & $\begin{array}{l}\text { Dwelling is suitably } \\
\text { warm in summer }\end{array}$ & Not selected & \\
\hline Suitably warm in winter & $\begin{array}{l}\text { What are the temperature conditions in your } \\
\text { dwelling? You may choose more than one option. }\end{array}$ & $\begin{array}{l}\text { Dwelling is suitably } \\
\text { warm in winter }\end{array}$ & Not selected & \\
\hline Traffic noise disturbance & $\begin{array}{l}\text { Which of the following causes noise disturbance } \\
\text { in your residence or residential environment and } \\
\text { how frequently? } \\
\text { - Road and street traffic }\end{array}$ & $\begin{array}{l}\text { Noise disturbance } \\
\text { daily/almost daily }\end{array}$ & $\begin{array}{l}\text { No noise disturbance } \\
\text { Noise disturbance } \\
\text { weekly } \\
\text { Noise disturbance } \\
\text { occasionally/season- } \\
\text { ally }\end{array}$ & \\
\hline Neighbour noise disturbance & $\begin{array}{l}\text { Which of the following causes noise disturbance } \\
\text { in your residence or residential environment and } \\
\text { how frequently? } \\
\text { - Noise from neighbour (from dwelling or balcony, } \\
\text { such as speech, music, the sound of footsteps, } \\
\text { etc.) }\end{array}$ & $\begin{array}{l}\text { Noise disturbance } \\
\text { daily/almost daily } \\
\text { Noise disturbance } \\
\text { weekly } \\
\text { Noise disturbance oc- } \\
\text { casionally/seasonally }\end{array}$ & No noise disturbance & \\
\hline Moisture or mould & $\begin{array}{l}\text { At present, is there any moisture or mould dam- } \\
\text { age in the main living space of your dwelling, and } \\
\text { what is the location and extent of the damage? } \\
\text { - Yes, on indoor surface }\end{array}$ & Yes & Not selected & \\
\hline
\end{tabular}

Dichotomized variables are shown by grouping in the third column, where 0 corresponds with the reference category.

*Options include: suitably warm, too cold, too hot, draughty, cold floor surfaces 


\begin{tabular}{|c|c|c|}
\hline $\begin{array}{l}\text { Block } 1 . \\
\text { A priori variables }\end{array}$ & Block 2. & Outcomes \\
\hline 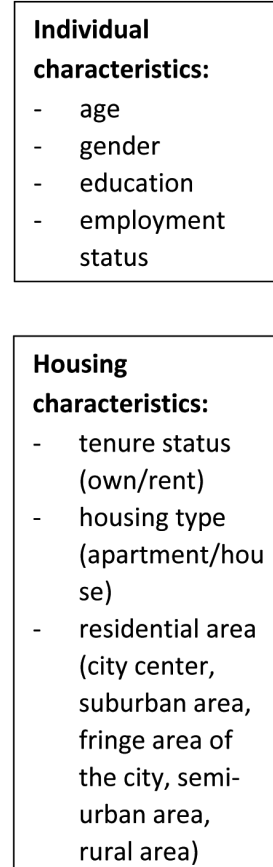 & 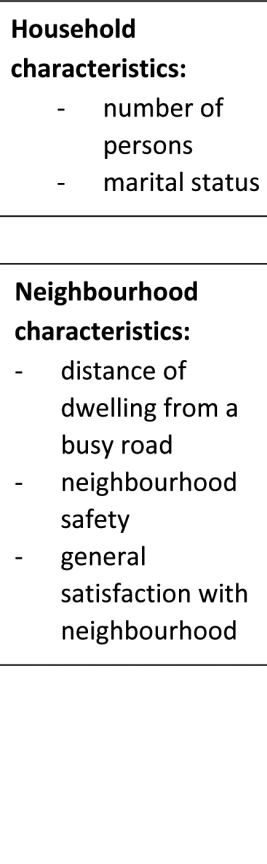 & $\begin{array}{l}\text { Housing } \\
\text { satisfaction } \\
\text { variables: } \\
\text { - } \quad \text { satisfaction } \\
\text { with the } \\
\text { dwelling } \\
\text { - } \quad \text { enough space } \\
\text { in dwelling } \\
\text { - } \quad \text { noise } \\
\text { disturbance } \\
\text { from traffic or } \\
\text { neighbour } \\
\text { - moisture or } \\
\text { mould } \\
\text { thermal comfort } \\
\quad \text { summer } \\
\quad \text { winter } \\
\text { indoor air } \\
\text { quality }\end{array}$ \\
\hline
\end{tabular}

Fig. 1. Schematic illustration of the multivariate logistic regression analyses.

demographic variables such as age, gender, and education and employment status that have frequently been related to housing conditions (13). Second step introduced variables from Block 2 in the models using stepwise procedure (entry when p-value $<0.05$ and removal when $p$-value $>0.10$ ). Level of statistical significance selected was $\mathrm{p}<0.05$. The statistical software used was IBM SPSS Statistics 22.0.

\section{RESULTS}

\section{Bivariate Associations}

Table 2 shows bivariate-associations between selected housing variables and residential areas, dwelling types and tenure status. There were statistically significant differences between the types of residential areas in satisfaction with IAQ, having enough space in the dwelling, thermal comfort in summer, and both traffic and neighbour noise disturbance. The raw differences between residential areas in the above mentioned housing variables ranged from $14 \%$ to $30 \%$. Overall, respondents in more sparsely populated areas reported being satisfied with their living environment more frequently than respondents from densely populated areas.

There were significant differences (raw prevalence differences ranging from $11 \%$ to $40 \%$ ) between dwelling types in all explored variables with an exemption of moisture or mould damage. Respondents living in houses reported better housing quality than respondents living in apartment blocks. With regard to tenure status, home owners reported significantly better housing quality than tenants in all explored aspects, raw prevalence differences ranging from $4 \%$ to $35 \%$.

\section{Multivariate Models}

Tables 3 and 4 show the results based on multiple logistic regression, where adjusted R-squares for different models varied from 0.12 to 0.35 . Residential area was statistically significantly associated with thermal conditions in summer and neighbour noise disturbance so that respondents from rural areas reported more suitable indoor summer temperature (OR 2.01, 95\% CI 1.12-3.60) and less noise disturbance (OR $0.30,95 \%$ CI $0.14-0.65$ ) than responders from city or town centres. Correspondingly, respondents from houses reported more suitable indoor summer temperature (OR 1.75 95\% CI 1.22-2.50) and less neighbour noise disturbance (OR $0.28,95 \%$ CI $0.19-0.41$ ) than respondents from apartments. In addition, house dwellers were more likely to be satisfied with the IAQ of their dwellings than apartment block dwellers (OR $1.60,95 \%$ CI 1.11-2.29).

Tenure status was statistically significantly associated with satisfaction with the dwelling and IAQ, enough space in the dwelling, and thermal conditions in winter: owner-occupiers were more likely to be satisfied compared to rental dwellers, with odds ratios ranging from 1.73-3.19. In addition, homeowners reported significantly less moisture or mould damage on interior surfaces (OR 0.37, 95\% CI 0.17-0.83) and neighbour noise disturbance (OR $0.60,95 \%$ CI $0.39-0.91$ ) than tenants.

With regard to socio-demographic and socioeconomic variables, men were statistically significantly more likely to be satisfied with winter thermal conditions than women. Older respondents were more likely to report dwelling having enough space. They were also more satisfied with winter and summer thermal conditions, and reported less neighbour noise disturbance than younger respondents. Respondents with higher levels of education more likely reported their dwellings suitably warm in 


\begin{tabular}{|c|c|c|c|c|c|c|c|c|c|c|c|c|}
\hline 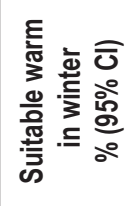 & & 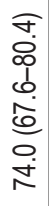 & 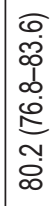 & $\mid \begin{array}{l}1 \\
0 \\
o 0 \\
0 \\
0 \\
0 \\
0 \\
0 \\
\omega \\
0 \\
0 \\
\infty\end{array}$ & $\mid \begin{array}{c}0 \\
0 \\
0 \\
0 \\
0 \\
0 \\
0 \\
0 \\
\dot{0} \\
\infty \\
\infty\end{array}$ & \begin{tabular}{|c|c|}
$\sigma$ \\
$o$ \\
$o$ \\
0 \\
0 \\
0 \\
0 \\
0 \\
0 \\
$\infty$ \\
$\infty$
\end{tabular} & 絭 & 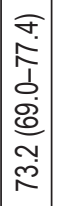 & 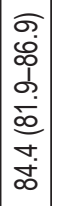 & * & 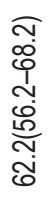 & 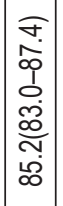 \\
\hline 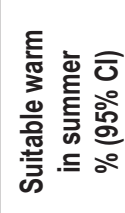 & 絭 & 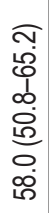 & 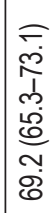 & 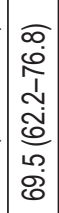 & \begin{tabular}{|c|}
0 \\
0 \\
0 \\
0 \\
0 \\
$\vdots$ \\
$\Sigma$ \\
0 \\
0 \\
0 \\
0
\end{tabular} & 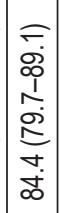 & 粋 & 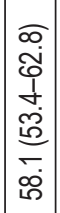 & 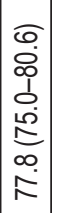 & 絭 & 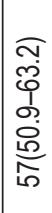 & 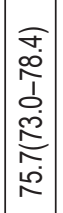 \\
\hline 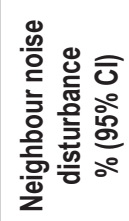 & * & 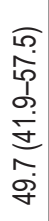 & 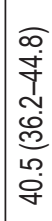 & 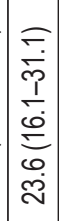 & 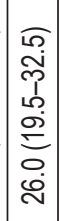 & 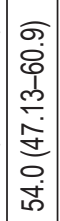 & 絭 & 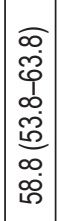 & 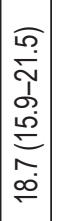 & * & 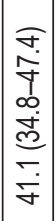 & 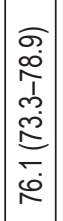 \\
\hline 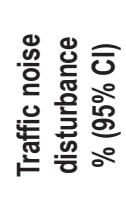 & * & 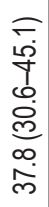 & 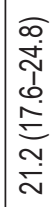 & 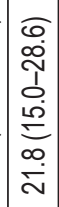 & 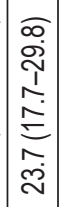 & 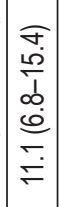 & * & 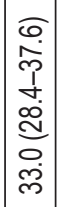 & 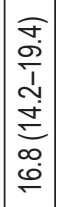 & * & 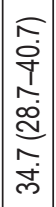 & 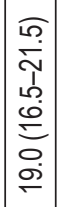 \\
\hline 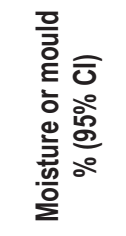 & & 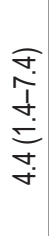 & $\begin{array}{l}\sigma \\
0 \\
0 \\
0 \\
0 \\
\tilde{j} \\
\tilde{\sigma} \\
\dot{\sigma}\end{array}$ & 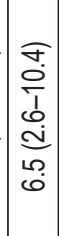 & 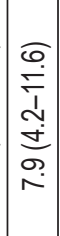 & 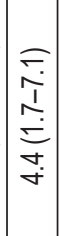 & & 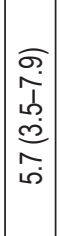 & $\mid$\begin{tabular}{l|}
0 \\
0 \\
0 \\
0 \\
0 \\
0 \\
0 \\
10
\end{tabular} & * & 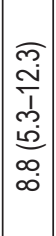 & 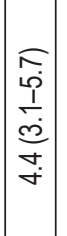 \\
\hline 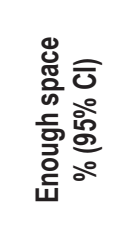 & 絭 & 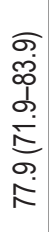 & $\begin{array}{c}0 \\
0 \\
0 \\
0 \\
1 \\
0 \\
0 \\
0 \\
0 \\
0 \\
\infty\end{array}$ & 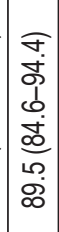 & 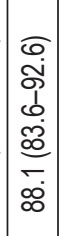 & 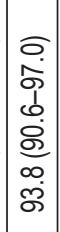 & * & 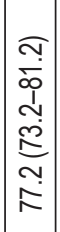 & 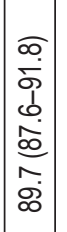 & 粋 & 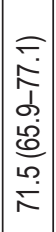 & 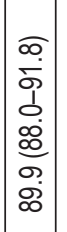 \\
\hline 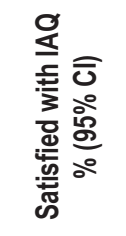 & * & 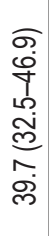 & 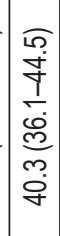 & $\begin{array}{l}\sigma \\
0 \\
0 \\
0 \\
\frac{1}{c} \\
\dot{+} \\
0 \\
0 \\
\dot{\sigma}\end{array}$ & 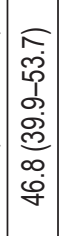 & 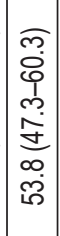 & * & 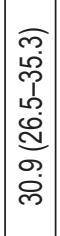 & 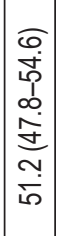 & * & 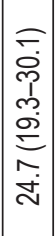 & 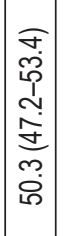 \\
\hline 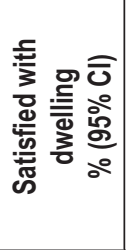 & & 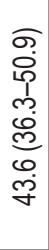 & 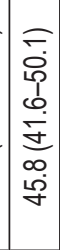 & 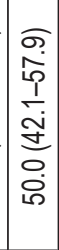 & 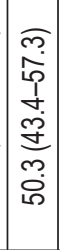 & 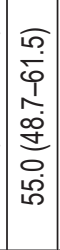 & * & 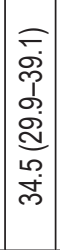 & 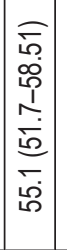 & 类 & 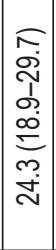 & 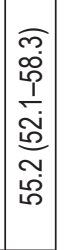 \\
\hline & 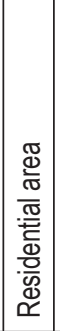 & 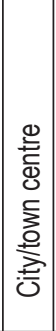 & 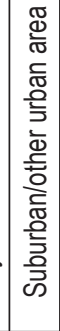 & 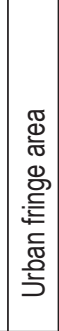 & 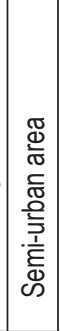 & 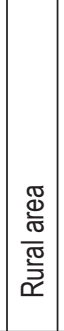 & 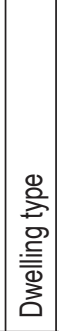 & 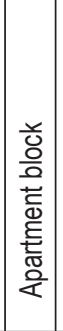 & $\begin{array}{l}\mathbf{w} \\
\mathbf{w} \\
\text { 호 } \\
\text { | }\end{array}$ & 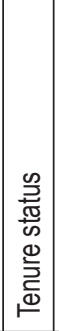 & & בิ \\
\hline
\end{tabular}

winter than respondents who had completed middle school only. With regard to occupation, students were less likely to be satisfied with their dwelling than respondents who were retired or not in the workforce. Self-employed persons were less likely to report neighbour noise disturbance.

With regard to household characteristics, both marital status and number of persons in the household were associated with "enough space" in the dwelling, and number of persons in the household was significantly associated with moisture or mould damage on interior surfaces.

From the variables indicating neighbourhood satisfaction, "neighbourhood safety" was associated with all dependent variables with an exception of thermal comfort in winter. Respondents who perceived their neighbourhood safe were more likely to be satisfied with their housing. Respondents who were generally more satisfied with their neighbourhood were more likely to be satisfied with their dwelling and IAQ. Distance from busy road was associated with noise disturbance from traffic.

\section{DISCUSSION}

Based on the results of this study, housing satisfaction varied by residential area, type of the dwelling, and tenure status; up to $40 \%$ differences were observed in the raw prevalence values between the sub-categories. In case a building owner or area developer would like to make a comparative assessment of housing satisfaction in a sample of dwellings using the results from the national housing and health survey as a reference, it would be important to take this variation into account by comparing the results with a corresponding sub-group of dwellings. For this purpose, we have also calculated the results (both prevalence values and $95 \%$ confidence intervals) of the national housing and health survey by residential area, type of the dwelling and tenure status, as indicated in Table 2. Alternatively, the sample of dwellings being assessed should be compared with a corresponding control group of dwellings matched by area, dwelling type and/or tenure status. Also socioeconomic and socio-demographic composition of the samples should be taken into consideration.

In general, utilizing questionnaire data carries the possibility for reporting bias. The response rate was $44 \%$, which is a possible limitation. As compared to the Finnish population and the original (random) sample from FPRC, among respondents women were overrepresented and mean age was higher (18). However, when producing age- and gender-weighted estimates corresponding to the population sample, the prevalence of housing factors remained largely unchanged (data not shown). Therefore, the data can be considered representative in terms of housing factors in Finland, and used as a reference material in future assessments.

Based on the results, tenure status and dwelling type were frequently associated with housing satisfaction. Higher satisfaction with winter temperature conditions among respondents of owner occupied dwellings may at least partly be related to that home owners have more control over the temperature conditions than residents in rental units. It is recommended that the differences in thermal conditions and IAQ between owned and rental apartments should be studied using measured data. Differences observed in summer thermal conditions by residential area could be related to the heat island effect, which means that urban areas are hotter than 
Table 3. Multivariate associations between independent variables and enough space in dwelling, satisfaction with dwelling and $I A Q$, and moisture or mould of interior surfaces

\begin{tabular}{|c|c|c|c|c|}
\hline & $\begin{array}{l}\text { Enough space } \\
\text { OR (95\% Cl) }\end{array}$ & $\begin{array}{l}\text { Satisfied with } \\
\text { dwelling } \\
\text { OR }(95 \% \mathrm{Cl})\end{array}$ & $\begin{array}{l}\text { Satisfied with IAQ } \\
\text { OR (95\% CI) }\end{array}$ & $\begin{array}{l}\text { Moisture or mould } \\
\text { of interior surfaces } \\
\text { OR }(95 \% \mathrm{Cl})\end{array}$ \\
\hline \multicolumn{5}{|l|}{ Residential area } \\
\hline Suburban or other urban residential area vs. city/town centre & $1.60(0.92-2.79)$ & $0.93(0.6-1.44)$ & $0.82(0.54-1.26)$ & $0.79(0.31-2.03)$ \\
\hline Urban fringe area vs. city/town centre & $1.90(0.83-4.34)$ & $0.93(0.52-1.64)$ & $1.06(0.61-1.84)$ & $1.15(0.34-3.94)$ \\
\hline Semi-urban area vs. city/town centre & $1.53(0.73-3.20)$ & $0.90(0.52-1.57)$ & $0.78(0.46-1.32)$ & $2.06(0.71-5.96)$ \\
\hline Rural area vs. city/town centre & $2.82(1.19-6.69)$ & $0.71(0.41-1.25)$ & $0.71(0.42-1.23)$ & $1.27(0.38-4.19)$ \\
\hline \multicolumn{5}{|l|}{ Dwelling type } \\
\hline House vs. apartment block & $1.23(0.73-2.08)$ & $1.35(0.93-1.96)$ & $1.60(1.11-2.29)$ & $1.37(0.61-3.09)$ \\
\hline \multicolumn{5}{|l|}{ Tenure status } \\
\hline Own vs. rent & $1.87(1.08-3.24)$ & $3.19(2.06-4.95)$ & $1.73(1.14-2.64)$ & $0.37(0.17-0.83)$ \\
\hline \multicolumn{5}{|l|}{ Gender } \\
\hline Male vs. female & $0.89(0.58-1.35)$ & $0.83(0.62-1.10$ & $1.19(0.91-1.56$ & $1.34(0.75-2.42)$ \\
\hline Age & $1.04(1.02-1.07)$ & $1.00(0.98-1.01)$ & $1.01(1.00-1.02)$ & $0.99(0.96-1.01)$ \\
\hline \multicolumn{5}{|l|}{ Education level } \\
\hline High school vs. primary/comprehensive/middle school & $0.98(0.40-2.41)$ & $1.45(0.71-2.95)$ & $0.68(0.35-1.32)$ & $0.23(0.04-1.17)$ \\
\hline $\begin{array}{l}\text { Professional qualification vs. primary/comprehensive/middle } \\
\text { school }\end{array}$ & $0.66(0.35-1.26)$ & $0.94(0.63-1.38)$ & $1.11(0.76-1.62)$ & $0.58(0.25-1.32)$ \\
\hline College degree vs. primary/comprehensive/middle school & $0.75(0.36-1.53)$ & $0.76(0.49-1.17)$ & $1.14(0.75-1.73)$ & $0.64(0.25-1.65)$ \\
\hline Academic degree vs. primary/comprehensive/middle school & $0.68(0.33-1.39)$ & $0.85(0.53-1.36)$ & $1.10(0.70-1.73)$ & $1.38(0.57-3.33)$ \\
\hline \multicolumn{5}{|l|}{ Occupational group } \\
\hline Student vs. retired/not in the workforce & $0.56(0.20-1.53)$ & $0.40(0.16-0.99)$ & $1.24(0.53-2.90$ & $1.21(0.29-5.16)$ \\
\hline Self-employed person vs. retired/not in the workforce & $1.09(0.40-2.97)$ & $1.27(0.71-2.28)$ & $1.19(0.68-2.07)$ & $0.31(0.06-1.58)$ \\
\hline Official/employer vs. retired/not in the workforce & $0.65(0.33-1.26)$ & $0.82(0.5-1.22)$ & $0.92(0.63-1.35)$ & $1.28(0.57-2.92)$ \\
\hline Executive superior official vs. retired/not in the workforce & $0.77(0.32-1.86)$ & $0.74(0.43-1.28)$ & $0.81(0.48-1.37)$ & $0.79(0.23-2.71)$ \\
\hline \multicolumn{5}{|l|}{ Marital status } \\
\hline Common-law marriage vs. single & $0.72(0.36-1.42)$ & - & - & - \\
\hline Marriage vs. single & $0.74(0.35-1.58)$ & - & - & - \\
\hline Divorced/widowed vs. single & $0.26(0.11-0.63)$ & - & - & - \\
\hline Number of persons in the household & $0.77(0.67-0.89)$ & - & - & $1.28(1.06-1.54)$ \\
\hline \multicolumn{5}{|l|}{ Safety of neighbourhood } \\
\hline Fairly safe vs. safe & $0.56(0.37-0.84)$ & $0.34(0.25-0.45)$ & $0.42(0.31-0.56)$ & $2.28(1.25-4.15)$ \\
\hline Rather unsafe/unsafe vs. safe & $0.22(0.08-0.58)$ & $0.31(0.11-0.88)$ & $0.12(0.03-0.51)$ & $3.16(0.79-12.65)$ \\
\hline \multicolumn{5}{|l|}{ General satisfaction with neighbourhood } \\
\hline Fairly satisfied vs. satisfied & - & $0.39(0.30-0.52)$ & $0.62(0.47-0.82)$ & - \\
\hline Rather unsatisfied/unsatisfied vs. satisfied & - & $0.26(0.14-0.49)$ & $0.31(0.16-0.59)$ & - \\
\hline Adjuster R-square & 0.23 & 0.27 & 0.20 & 0.12 \\
\hline
\end{tabular}

Statistically significant OR's $(95 \% \mathrm{Cl})$ are written in bold

rural areas due to heat stored in building materials, such as asphalt, concrete, etc. (19). In addition, the longer distances between neighbours as well as distance from busy roads can explain the decreased risk for noise disturbance in sparsely populated areas.

With regard to neighbourhood characteristics, safety of neighbourhood was most often associated with housing satisfaction. Interestingly, it also appears that safety is associated with distance from busy road. Neighbour noise disturbance might indicate general restlessness in the area, which can increase feeling of insecurity.

Observed associations between satisfaction with the neighbourhood, the dwelling and IAQ can refer to tendency of some respondents to give similar answers. It was also noticed that some of the bivariate associations observed became non-significant following the multivariate logistic regression analyses. This could be partially due to the associations between independent variables 
Table 4. Multivariate associations between independent variables and traffic and neighbour noise disturbance, and thermal comfort

\begin{tabular}{|c|c|c|c|c|}
\hline & $\begin{array}{l}\text { Traffic noise } \\
\text { disturbance } \\
\text { OR }(95 \% \mathrm{Cl})\end{array}$ & $\begin{array}{l}\text { Neighbour noise } \\
\text { disturbance } \\
\text { OR }(95 \% \text { Cl) }\end{array}$ & $\begin{array}{l}\text { Suitable warm } \\
\text { in summer } \\
\text { OR }(95 \% \mathrm{Cl})\end{array}$ & $\begin{array}{l}\text { Suitable warm } \\
\text { in winter } \\
\text { OR }(95 \% \mathrm{Cl})\end{array}$ \\
\hline \multicolumn{5}{|l|}{ Residential area } \\
\hline $\begin{array}{l}\text { Suburban area or other urban residential area vs. city/town } \\
\text { centre }\end{array}$ & $0.61(0.37-1.00)$ & $1.22(0.78-1.90)$ & $1.32(0.89-1.98)$ & $1.18(0.75-1.86)$ \\
\hline Urban fringe area vs. city/town centre & $0.99(0.51-1.93)$ & $0.68(0.35-1.31)$ & $1.01(0.59-1.74)$ & $1.18(0.62-2.23)$ \\
\hline Semi-urban area (e.g. parish village) vs. city/town centre & $1.08(0.57-2.05)$ & $1.19(0.66-2.15)$ & $1.51(0.88-2.59)$ & $1.02(0.56-1.86)$ \\
\hline Rural area vs. city/town centre & $0.92(0.44-1.94)$ & $0.30(0.14-0.65)$ & $2.01(1.12-3.60)$ & $1.05(0.56-1.96)$ \\
\hline \multicolumn{5}{|l|}{ Dwelling type } \\
\hline House vs. apartment block & $0.81(0.52-1.26)$ & $0.28(0.19-0.41)$ & $1.75(1.22-2.50)$ & $1.24(0.82-1.88)$ \\
\hline \multicolumn{5}{|l|}{ Tenure status } \\
\hline Own vs. rent & $0.85(0.53-1.37)$ & $0.60(0.39-0.91)$ & $1.30(0.88-1.91)$ & $2.63(1.74-3.97)$ \\
\hline \multicolumn{5}{|l|}{ Gender } \\
\hline Male vs. female & $1.08(0.76-1.55)$ & $0.79(0.57-1.10)$ & $1.27(0.95-1.70)$ & $1.69(1.21-2.35)$ \\
\hline Age & $0.99(0.98-1.01)$ & $0.96(0.95-0.98)$ & $1.03(1.01-1.04)$ & $1.02(1.01-1.04)$ \\
\hline \multicolumn{5}{|l|}{ Education } \\
\hline High school vs. primary/comprehensive/middle school & $1.06(0.49-2.31)$ & $1.05(0.50-2.21)$ & $1.20(0.62-2.32)$ & $2.47(1.18-5.16)$ \\
\hline $\begin{array}{l}\text { Professional qualification vs. primary/comprehensive/middle } \\
\text { school }\end{array}$ & $0.65(0.40-1.07)$ & $0.94(0.58-1.50)$ & $1.22(0.82-1.82)$ & $1.50(0.97-2.32)$ \\
\hline College degree vs. primary/comprehensive/middle school & $0.57(0.32-1.00)$ & $1.06(0.63-1.77)$ & $0.99(0.63-1.54)$ & $2.15(1.26-3.65)$ \\
\hline Academic degree vs. primary/comprehensive/middle school & $0.68(0.38-1.21)$ & $1.33(0.78-2.27)$ & $1.11(0.69-1.78)$ & $1.44(0.85-2.45)$ \\
\hline \multicolumn{5}{|l|}{ Occupational group } \\
\hline Student vs. retired/not in the workforce & $0.82(0.32-2.11)$ & $0.32(0.26-1.49)$ & $1.64(0.75-3.59)$ & $1.01(0.44-2.29$ \\
\hline Self-employed person vs. retired/not in the workforce & $0.85(0.39-1.89)$ & $0.40(0.18-0.89)$ & $1.09(0.59-2.01)$ & $1.12(0.57-2.23)$ \\
\hline Official/employer vs. retired/not in the workforce & $1.13(0.68-1.88)$ & $0.72(0.46-1.14)$ & $1.03(0.68-1.54)$ & $1.18(0.76-1.86)$ \\
\hline Executive superior official vs. retired/not in the workforce & $1.10(0.53-2.28)$ & $1.04(0.56-1.92)$ & $1.41(0.77-2.56)$ & $1.05(0.53-2.05)$ \\
\hline \multicolumn{5}{|l|}{ Safety of neighbourhood } \\
\hline Fairly safe vs. safe & $2.51(1.75-3.60)$ & $1.87(1.35-2.58)$ & $0.70(0.53-0.94)$ & - \\
\hline Rather safe/unsafe vs. safe & $4.52(1.86-11.01)$ & $2.45(1.01-5.97)$ & $0.37(0.17-0.82)$ & - \\
\hline \multicolumn{5}{|l|}{ Distance from busy road (m) } \\
\hline$>20-50$ vs. $0-20$ & $0.47(0.26-0.83)$ & - & - & - \\
\hline$>50-200$ vs. $0-20$ & $0.27(0.16-0.45)$ & - & - & - \\
\hline$>200-500$ vs. $0-20$ & $0.22(0.13-0.38)$ & - & - & - \\
\hline$>500$ vs. $0-20$ & $0.10(0.05-0.18)$ & - & - & - \\
\hline Adjuster R-square & 0.24 & 0.35 & 0.13 & 0.13 \\
\hline
\end{tabular}

Statistically significant OR's $(95 \% \mathrm{Cl})$ are written in bold

included in the models, such as age, marital status, tenure, type of dwelling, and residential area. For example, older people are more likely to be married and to live in owner-occupied dwellings $(20,21)$. Houses (including row house and semi-detached) are more likely to be owned by the occupants than apartments, which are more commonly rented.

The adjusted R-squares of multivariable models varied from $12-35 \%$, which means that a large part of the variation in the dependent variables is explained by factors other than those covered in this study. However, this is a typical range in non-experimental (general population-based) environmental health research. It was noted that adjusted R-squares were relatively higher for neighbour noise disturbance and general satisfaction with the dwelling, whereas the lowest R-squares were observed for thermal conditions and moisture or mould damage on interior surfaces.

In this study, gender, age and marital status were used as socio-demographic variables. Education, occupation group and tenure status are indicators of socioeconomic position (8-10, $22,23)$. Tenure status is also associated with income: in Finland in 2010 the disposable income per consumption unit was 1.67 
times higher for those who owned their dwellings than for tenants (24). Moreover, half of owner-occupier households are free from debt in Finland. Therefore, dwelling type is also associated with income and wealth (25).

Associations between tenure status and housing satisfaction have been reported in other studies. For example, Ellaway and Macintyre (26) found that tenants reported statistically significantly more housing problems related to noise from outside, dampness and/or condensation or keeping their homes warm in winter than owner-occupiers. In Finland, this is a relatively new research area, which makes interpretation of the results challenging. The result of the Residents Barometer 2004 targeting population centres (population $>10,000$ ) were similar to our study, the highest grades of satisfaction with dwelling were given by residents living in detached, semi-detached and row houses, and areas other than city centres and suburban areas (27). In addition, traffic noise disturbance was reported most often by residents of apartment blocks and city centres, which was also observed in our study.

\section{CONCLUSIONS}

According to this study, the most important factors determining differences in housing satisfaction were tenure status and type of the dwelling. Respondents from rental apartments perceived worse housing satisfaction related to IAQ and neighbour noise, and also space in the dwelling, satisfaction with the dwelling, moisture or mould damage on interior surfaces, and thermal comfort in winter. Living in apartments was associated with increased dissatisfaction with thermal conditions in summer. Further studies using objective measurements are recommended for more thorough assessment of observed differences by tenure status and dwelling type.

\section{Acknowledgements}

We would like to thank Veli-Matti Poutanen, Mari Turunen and Ari Paanala for comments, and Asko Vepsäläinen for helping with statistics. We would also like to thank Mark Phillips for the language editing. The study was financially supported by the Academy of Finland (decision number 109062), the Ministry of Environment, the Housing Finance and Development Centre of Finland, and the Olvi Foundation. The study plan was evaluated and approved by the Ethical Committee of the National Institute for Health and Welfare.

\section{Conflict of Interests}

None declared

\section{REFERENCES}

1. Jantunen MJ, Hänninen O, Katsouyanni K, Knöppel H, Künzli N, Lebret E, Maroni M, Saarela K, Srám R and Zmirou D. Air pollution exposure in European cities: the "EXPOLIS" study. J Expo Anal Environ Epidemiol. 2008;8:495-518.

2. Dales R, Liu L, Wheeler AJ, Gilbert NL. Quality of indoor residential air and health. CMAJ. 2008 Jul 15;179(2):147-52.

3. Heseltine E, Rosen J, editors. WHO guidelines for indoor air quality: dampness and mould. Copenhagen: WHO Regional Office for Europe; 2009.

4. van Kempen EE, Kruize H, Boshuizen HC, Ameling CB, Staatsen BA, de Hollander AE. The Association between noise exposure and blood pressure and ischemic heart disease: a meta-analysis. Environ Health Perspect. 2002 Mar;110(3):307-17.
5. Ndrepepa A, Twardella D. Relationship between noise annoyance from road traffic noise and cardiovascular diseases: a meta-analysis. Noise Health. 2011 May-Jun;13(52):251-9.

6. Passchier-Vermeer W, Passchier WF. Noise exposure and public health. Environ Health Perspect. 2000 Mar;108 Suppl 1:123-31.

7. Willich SN, Wegscheider K, Stallmann M, Keil T. Noise burden and the risk of myocardial infarction. Eur Heart J. 2006 Feb;27(3):276-82.

8. Dunn JR, Hayes MV. Social inequality, population health, and housing: a study of two Vancouver neighborhoods. Soc Sci Med. 2000 Aug;51(4):563-87.

9. Bambra C, Gibson M, Sowden A, Wright K, Whitehead M, Petticrew M. Tackling the wider social determinants of health and health inequalities: evidence from systematic reviews. J Epidemiol Community Health. 2010 Apr;64(4):284-91.

10. Braubach M, Fairburn J. Social inequities in environmental risks associated with housing and residential location - a review of evidence. Eur J Public Health. 2010 Feb;20(1):36-42.

11. Northridge J, Ramirez OF, Stingone JA, Claudio L. The role of housing type and housing quality in urban children with asthma. J Urban Health. 2010 Mar;87(2):211-24.

12. Rauh VA, Landrigan PJ, Claudio L. Housing and health - intersection of poverty and environmental exposures. Ann N Y Acad Sci. 2008;1136:27688.

13. Environmental health inequalities in Europe. Assessment report. Copenhagen: WHO Regional Office for Europe; 2012.

14. Moisio P. Development of income inequality, poverty, and difficulties in making the living. In: Vaarama M, Moisio P, Karvonen S, editors. Finns' walfare 2010. Helsinki: Yliopistopaino; 2010. p. 180-96. (In Finnish.)

15. OECD. Growing Unequal? Income distribution and poverty in OECD countries. Paris: OECD Publishing; 2008.

16. Finlex [Internet]. Helsinki: Ministry of Justice, Finland; 2001 [cited 2014 Jun 12]. Finnish Personal Data Act 523/1999 English. Available from: http://www.finlex.fi/en/laki/kaannokset/1999/en19990523.

17. Turunen M, Paanala A, Villman J, Nevalainen A, Haverinen-Shaughnessy U. Evaluating housing quality, health and safety using an Internet-based data collection and response system: a cross-sectional study. Environ Health. 2010 Nov 12;9:69.

18. Official Statistics of Finland (OSF). Population structure [Internet]. Helsinki: Statistics Finland; 2012 [cited 2012 Dec 17]. Available from: http://www.tilastokeskus.fi/til//vaerak/tau_en.html.

19. Suomi J, Käyhkö J. The impact of environmental factors on urban temperature variability in the coastal city of Turku, SW Finland. Int J Climatol. 2012 Mar;32(3):451-63.

20. Official Statistics of Finland (OSF). Dwellings and housing conditions [Internet]. Helsinki: Statistics Finland; 2012 [cited 2012 Sep 4]. 2. Household-dwelling units and housing conditions 2010. Available from: http://www.tilastokeskus.fi/til/asas/2010/01/asas_2010_01_2011-1020 kat 002 en.html.

21. Official Statistics of Finland (OSF). Changes in marital status [Internet]. Helsinki: Statistics Finland; 2010 [cited 2012 Sep 4]. Available from: http://www.stat.fi/til/ssaaty/2010/ssaaty_2010_2011-05-06_tie_001_ en.html.

22. Galobardes B, Shaw M, Lawlor DA, Lynch JW, Davey Smith G. Indicators of socioeconomic position (part 1). J Epidemiol Community Health. 2006 Jan;60(1):7-12.

23. Sundquist J, Johansson SE. Indicators of socio-economic position and their relation to mortality in Sweden. Soc Sci Med. 1997 Dec;45(12):1757-66.

24. Official Statistics of Finland (OSF). Income distribution statistics [Internet]. Helsinki: Statistics Finland; 2010 [cited 2012 May 24]. Available from: http://www.tilastokeskus.fi/til/tjt/2010/tjt_2010_201205-23 tie 001 en.html.

25. Juntto A. Change and future of housing. Structural evaluation. Housing segregation, subproject I. Helsinki: Ministry of the Environment, 2008. (In Finnish.)

26. Ellaway A, Macintyre S. Does housing tenure predict health in the UK because it exposes people to different levels of housing related hazards in the home or its surroundings? Health Place. 1998 Jun;4(2):141-50.

27. Strandell A. Resident barometer 2004. Occupant questionnaire on Finnish living environment. Helsinki: Ministry of the Environment; 2005. (In Finnish.) 